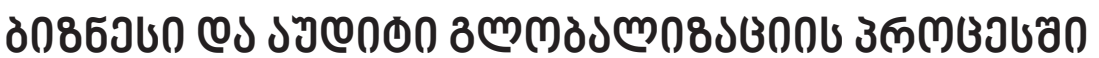

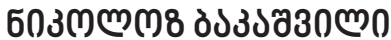

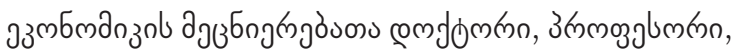

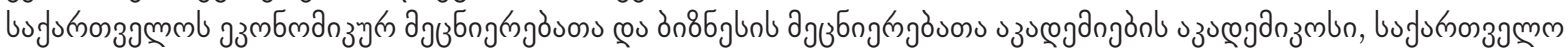

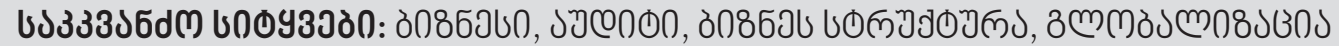

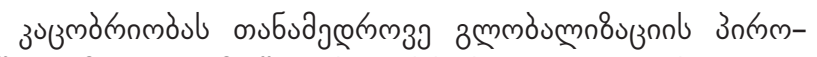

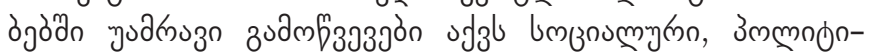

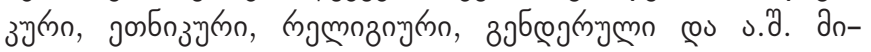

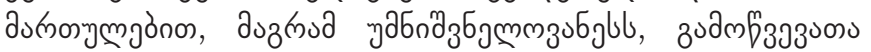

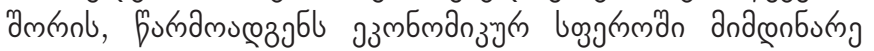

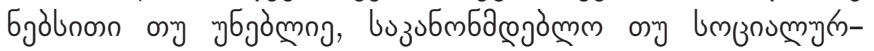

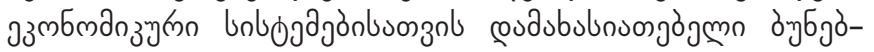

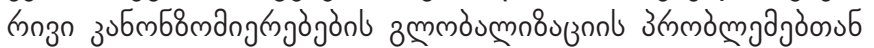

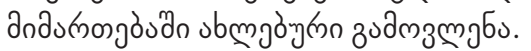

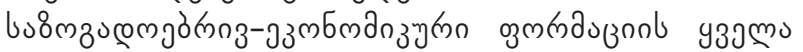

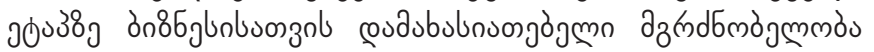

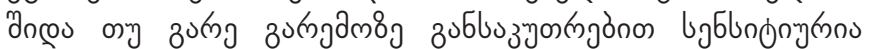

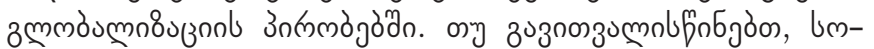

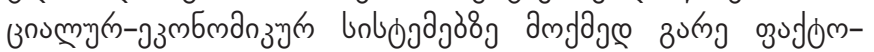

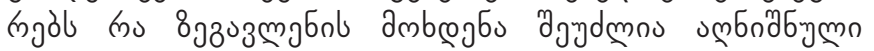
бов

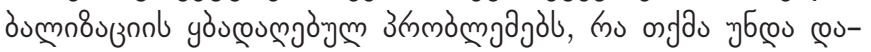

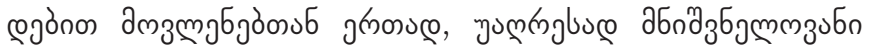

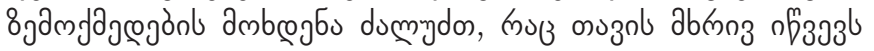

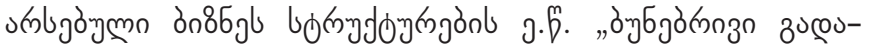

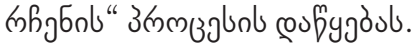

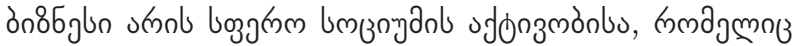

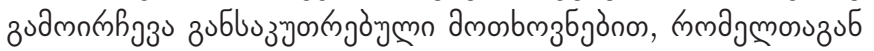

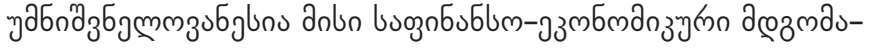

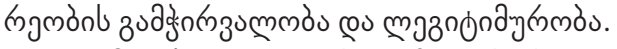

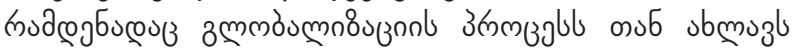

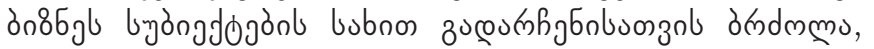
uмб

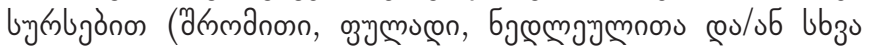
dudgตn

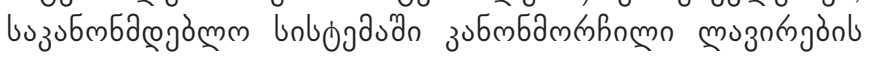

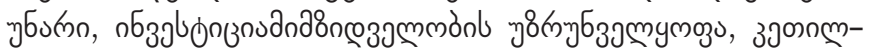

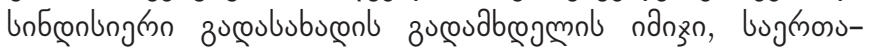

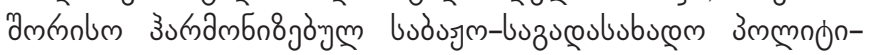

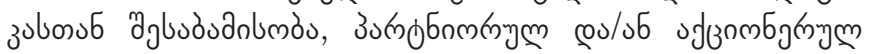
उ०उnou

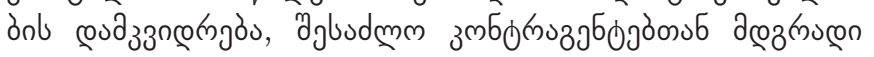

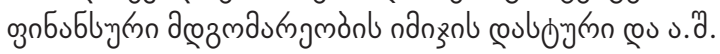

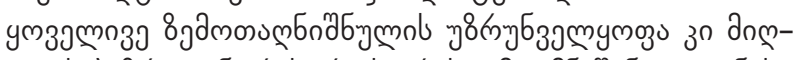

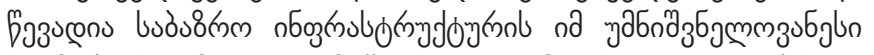

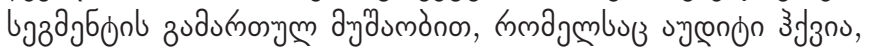

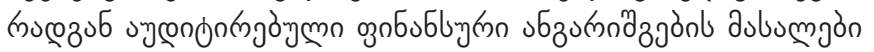

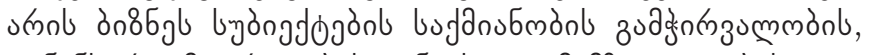

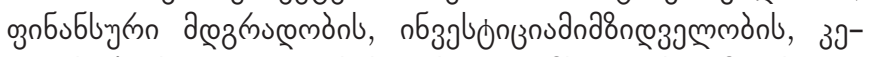

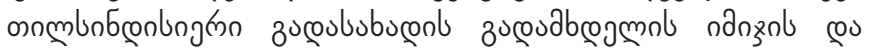

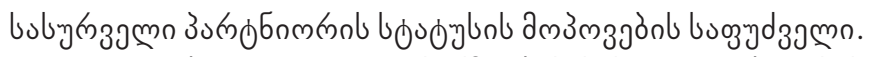

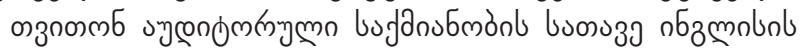

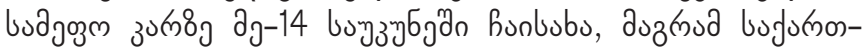

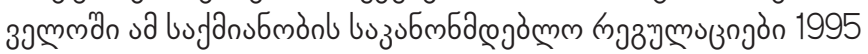

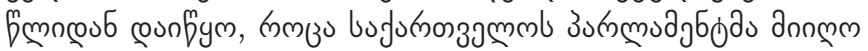

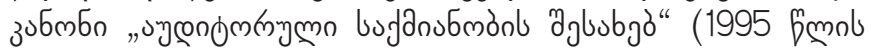

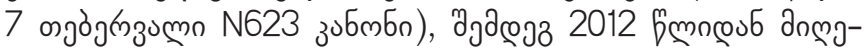

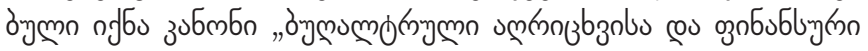

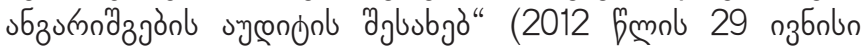

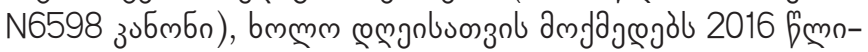

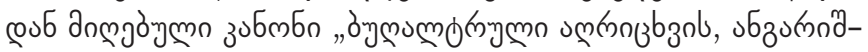

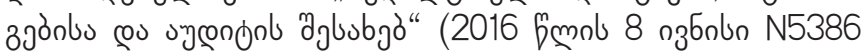
उзбmbn).

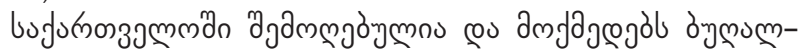

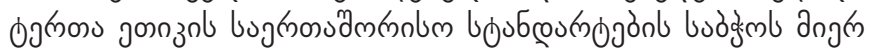

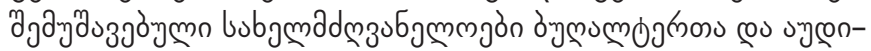

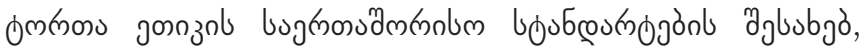

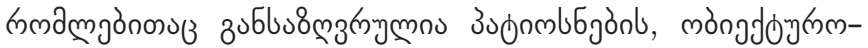

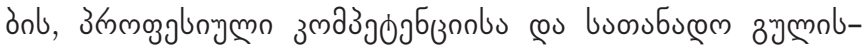

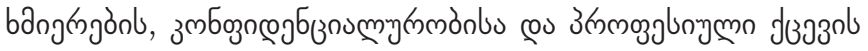
Бmmajòn.

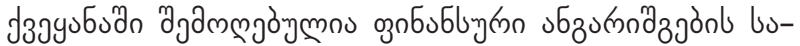

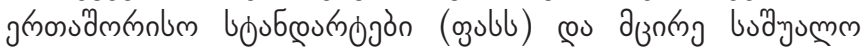

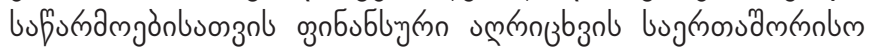
boubcostrogón (abl ogubu).

sbumn zubmbnl samjagejònbonubuza agnjabu bufuknom-

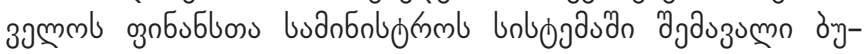

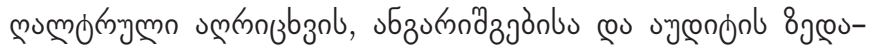

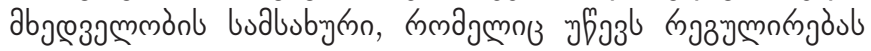

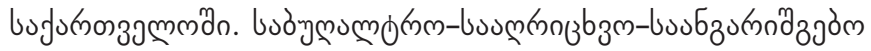

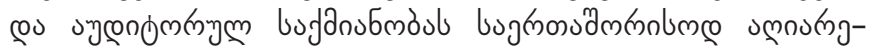

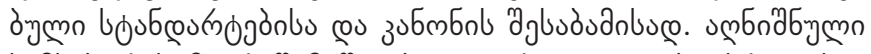

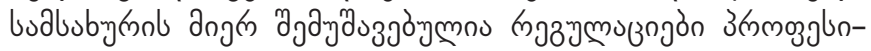

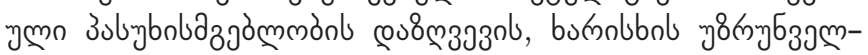

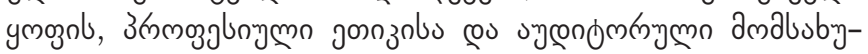

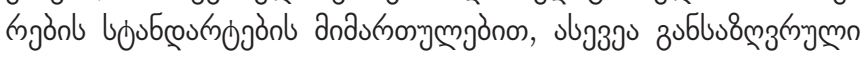

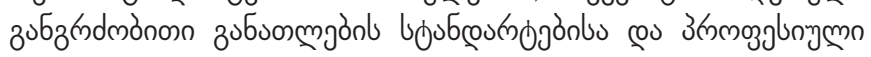

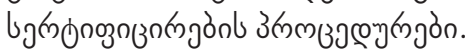

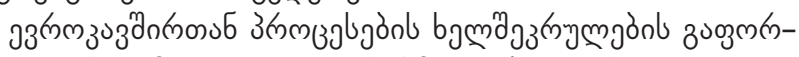

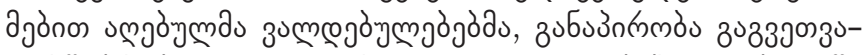

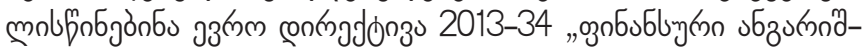

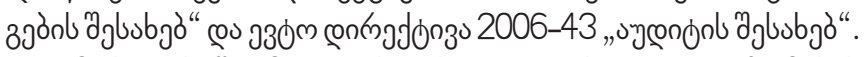

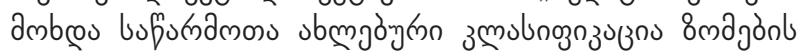

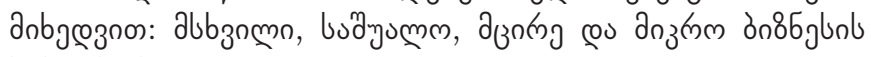
unòjdojouce. 


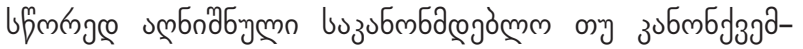
œgò

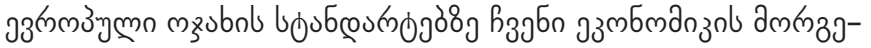

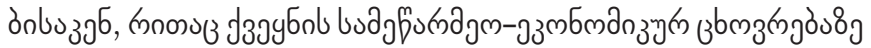

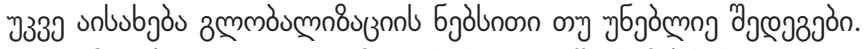

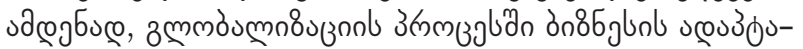

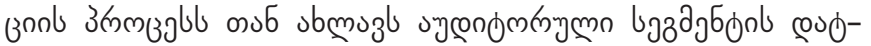

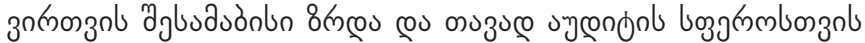

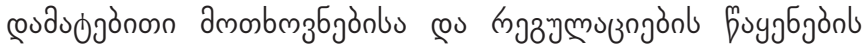

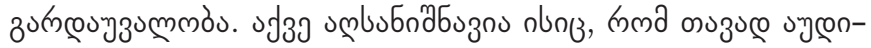

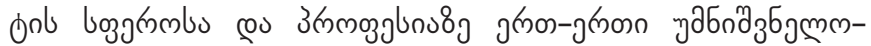

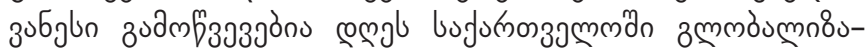

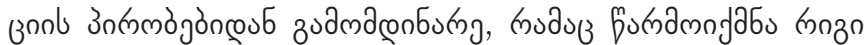

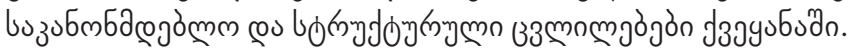

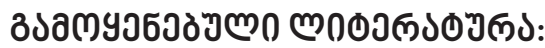

1. Barrett, M., Cooper, D. and Jamal, K. 2005. 'Globalization and the Coordinating of Work in Multinational Audits', Accounting Organizations and Society 30(1): 1-24.

2. Bell, T., Peecher, M. and Solomon, I. 2005. The 21st Century Public-Company Audit: Conceptual Elements of KPMG's Global Audit Methodology. Montvale, NJ: KPMG.

3. Bishop, C.C., Hermanson, D.R. and Houston, R.W. 2012. 'PCAOB Inspections of International Audit Firms: Initial Evidence', International Journal of Auditing 17(1): 1-18.

4. Carcello, J. , Carver, B. and Neal, T. 2011. 'Market Reaction to the PCAOB's Inability to Conduct Foreign Inspections', SSRN. Available at http://ssrn.com/abstract=1911388 (accessed 19 July 2013).

5. Carson, E., Simnett, R., Soo, B.S. and Wright, A.M. 2012. 'Changes in Audit Market Competition and the Big N Premium', Auditing: A Journal of Practice \& Theory 31 (3): 47-73.

6. Choi, J.H. and Wong, T.J. 2007. 'Auditors' Governance Functions and Legal Environments: An International Investigation', Contemporary Accounting Research 24(1): 13-46.

7. Deumes, R., Schelleman, C., Vander Bauwhede, H. and Vanstraelen, A. 2012. 'Audit Firm Governance: Do Transparency Reports Reveal Audit Quality?', Auditing: A Journal of Theory and Practice 31(4): 193-214.

8. European Commission (EC). 2010. Audit Policy: Lessons from the Crisis. Available online at http://europa.eu/rapid/pressReleasesAction.do?reference=IP/10/1325\&format=HTML\&aged=0\&language=EN\&guiLanguage=en (accessed 19 July 2013 ).

9. Francis, J.R. 2011. 'Auditing without Borders', Accounting, Organizations and Society 36(4-5): 318-323.

10. Francis, J.R. and Wang, D. 2008. 'The Joint Effect of Investor Protection and Big 4 Audits on Earnings Quality around the World', Contemporary Accounting Research 25(1): 157-191.

11. Francis, J.R., Michas, P.N. and Seavey, S. 2013. 'Does Audit Market Concentration Harm the Quality of Audited Earnings? Evidence from Audit Markets in 42 Countries', Contemporary Accounting Research 30(1): 325-355.

12. General Accounting Office (GAO). 2003. Public Accounting Firms: Mandated study on consolidation and competition. GAO-03-864. Washington, DC: General Accounting Office.

13. House of Lords Economic Affairs Committee. 2011. Auditors: Market Concentration and their Role. Available online at www.parliament.uk/business/committees/committees-a-z/lords-select/economic-affairs-committee/publications/ (accessed 19 July 2013).

14. Humphrey, C., Loft, A. and Woods, M. 2009. 'The Global Audit Profession and the International Financial Architecture: Understanding regulatory relationships at a time of financial crisis', Accounting, Organizations and Society 34(6-7): 810-825.

15. Jenner and Block. 2010. Lehman Brothers Holdings Inc. 'Chapter 11 Proceedings Examiner Report'. Available online at http://jenner.com/lehman/ (accessed 19 July 2013).

16. Maijoor, S. and Vanstraelen, A. 2012. 'Research Opportunities in Auditing in the EU Revisited', Auditing: A Journal of Practice and Theory 31(1): 115-126.

17. Michas, P.N. 2011. 'The Importance of Audit Profession Development in Emerging Market Countries', The Accounting Review 86(5): 1731-1764.

18. Verleyen, I., and De Beelde, I. 2011. 'International Consistency of Auditor Specialization', International Journal of Auditing 15(3): 275-287. 


\title{
BUSINESS AND AUDIT IN THE PROCESS OF GLOBALIZATION
}

\author{
NIKOLOZ BAKASHVILI
}

https://doi.org/10.35945/gb.2017.03.008

Doctor of Economic Sciences, Professor,

Academician of the Academies of Economic and Business Sciences of Georgia, Georgia

KEYWORDS: BUSINESS, AUDIT, BUSINESS STRUCTURE, GLOBALIZATION

\section{SUMMARY}

Humanity has a lot of challenges in regard of social, political, ethnic, religious, gender etc. direction within the context of modern globalization, but innovative reveal of the natural regularities in regard of the globalization process characteristic of legislative and social-economic systems taking place willfully or involuntarily, can be considered as the most important one among the mentioned challenges.

Sensitivity of business to the internal or external environment characteristic of business within the conditions of globalization can be considered as especially sensitive at all stages of the social-economic formation. If we take into consideration the impact of external factors, affecting socialeconomic systems, on the economic behavior of the mentioned business structures, the problems related to globalization can have extremely important impact together with the positive events. The latter, on its side, causes the start of so-called "natural survival process" of existing business structures.

Business is the field of activity of society distinguished with special requirements. Transparency and legitimacy of the financial-economic situation can be considered as the most important among the mentioned requirements.

Since the globalization process is accompanied by the strife for survival in a form of business subjects relevant resources (labor, financial, material and/or other material or non-material) will be provided. This may contain: ability to make law-abiding maneuvering within the legislative system, attractiveness of investment, image of honest taxpayer, compliance with the international harmonized customstax system, establishment of trust and transparency by the participants of partner and/or equity capital, confirmation of stable financial image with possible contractors and so on.

All the above mentioned can be achieved through proper working of the most important segment of market infrastructure such as audit. Materials of audited financial statements form the basis of transparency of working of business subjects, financial stability, image of honest tax payer and obtaining of desired partner status.

Herein, business adaptation process is accompanied by the relevant increase of load of audit segment and inevitability of additional requirements and regulations for the field of audit within the globalization process. It should also be noted that important challanges can be perceived in regard of audit profession and auditorial activity as well that is caused by the process of globalization. That caused a number of legislative and structural changes in the country on its side. 